\title{
Functional zoning and space management of Three-River-Source National Park
}

\author{
FU Mengdi ${ }^{1}$, TIAN Junliang ${ }^{2}$, REN Yueheng ${ }^{1}$, LI Junsheng ${ }^{1}$, LIU Weiwei ${ }^{1}$, \\ "ZHU Yanpeng ${ }^{1}$ \\ 1. State Key Laboratory of Environmental Criteria and Risk Assessment, State Environmental Protection Key \\ Laboratory of Regional Eco-process and Function Assessment, Chinese Research Academy of Environ- \\ mental Sciences, Beijing 100012, China; \\ 2. Three-River-Source National Park Administration, Xining 810007, China
}

\begin{abstract}
Functional zoning is a key step for the integrated planning and scientific management of a national park. Selecting the Three-River-Source National Park (TNP) as the study area, this paper establishes an evaluation system including 13 evaluation indexes which are classified into four categories, namely: ecosystem services; potential distribution of key species habitats; ecological sensitivity; and ecological resilience through the comprehensive analysis on the regional eco-environmental features in the study area. The results of the comprehensive analysis, combined with the functions and requirements of management of national parks, indicate that TNP is divided into the first-level zone (the core conservation area, the ecological restoration area and the traditional utilization area) with definite targets of space management and the second-level zone with implementation of control measures. This method of functional zoning lays a solid foundation for the scientific planning of TNP; moreover, our study provides new insights into other national parks' functional zoning.
\end{abstract}

Keywords: national parks; Three-River-Source National Park (TNP); functional zoning; index system; space management

\section{Introduction}

A national park is an area adhering to sustainable development to strictly protect and make reasonable utilization of natural and cultural resources (Chen et al., 2014). The Third Plenary Session of the 18th Central Committee of the CPC proposed the establishment of a national park system. In order to promote the establishment of national park system, 13 ministries and commissions including the National Development and Reform Commission issued the Pilot Program for Establishing the National Park System, and selected Qinghai as the site for the pilot program. The Three-River-Source region in Qinghai is an important barrier for the ecological safety of China, as well as an important source of fresh water and the area

Received: 2018-09-12 Accepted: 2019-03-10

Foundation: National Key Research and Development Program of China, No.2017YFC0503806

Author: Fu Mengdi (1987-), E-mail: mengdi_fu@163.com

*Corresponding author: Zhu Yanpeng (1983-), PhD, E-mail: zhuyp@craes.org.cn 
with the most diversified plateau species. The Three-River-Source region possesses an ecosystem of high authenticity and integrity, and preserves rich traditional cultural resources. However, the eco-environment of the Three-River-Source region is fragile and sensitive to climate change. Once it is disturbed, its ecological functions would be degenerated, which will impair the ecological safety and the long-term development of China. Therefore, it is very important to carry out the pilot program for establishing a national park in the Three-River-Source region, in order to strengthen the protection of the integrity and authenticity of the ecological system in this area, study the establishment of the national park system, and coordinate the ecological protection and the comprehensive development of regional economy and society.

As an integral part of the overall planning of a national park, functional zoning specifies the requirements of space and management for the protection and utilization of a national park. The zoning of national parks in the United States has evolved from the dichotomization into the trichotomy using the Outdoor Recreation Resources Review Commission (ORRRC) zoning model which divides national parks into recreational areas with high density of visitors, general outdoor recreational areas, natural areas, special natural areas, primitive areas, and historical and cultural sites which optimizes a national park's function (NPS, 2009; Dilsaver, 1994). National parks in Canada are divided into special protected areas, wilderness areas, natural areas, outdoor recreational areas and park service areas in accordance with the protection requirements of ecological systems and cultural resources, the existing and potential opportunities for tourists and their impacts, so as to protect the natural environment effectively and ensure that their national parks serve the people (Price, 1983). Japan categorizes its national parks according to the importance of the protected objects and the intensity of exploitation and utilization, a national park of Japan is divided into special protected areas, special areas (divided into level-I, level-II and level-III), general areas, and parks in the sea. This arrangement offers a clear boundary between the protected target and the sustainable utilization $(\mathrm{Xu}, 2013)$. In Taiwan, a national park is divided into ecological protection areas, special landscape areas, heritage preservation areas, recreational areas and general control areas according to the characteristics of resources and the pattern of land use. Different measures are taken for different zones for the protection and utilization (Chen, 2015). National parks in different regions are diverse, their physical geography, social economy and protected objects are different, making their functional zoning different. However, in general, the organization of national parks is based on the structure of three layers proposed by UNESCO, and the tension between humans and land determines the areas of each functional zone (Huang et al., 2007).

Every country has its own theoretical framework for the functional zoning of national parks, which generally includes the determination of protected objects and targets, resource assessment, decision-making of management and formulation of monitoring schemes (Margules and Pressey, 2000). The protected objects are the characteristics or elements of biodiversity in the national park, such as the biological feature (species and community), or the environmental factor (geology, climate, etc.). The determination of the protection targets is based on the main protected objects, and its importance to different parties' interests. The protection targets of different levels are determined through balancing the protection and sustainable utilization with the help of interviews of experts (Groves et al., 2002). As one of 
the most important methods for the functional zoning of national parks, the resource assessment would determine the protection level of resources mainly through valuing the biodiversity, the survivability and ecological integrity of the protected objects (Anderson, 1999), the ecological vulnerability, the sensitivity to climate change (Scott et al., 2002), the ecological carrying capacity and the threat factors. According to the results of assessment, a park would be divided into several functional zones. In addition, the historical and cultural values of important resources should be assessed to protect the original natural and cultural resources to the greatest extent. The management decision would coordinate the relationship between different protection targets and the managers or participants through the functional zoning to maximize the effectiveness of management. The decision-making involves the protection of natural and cultural resources, the visitor experience and education and the promotion of community development. The early warning system with the participation of different interest groups (park managers, visitors and community residents) (Puhakka and Saarinen, 2013) and the Public Participation Geographic Information System (PPGIS) (Brown and Weber, 2011) have gradually become important ways for making decisions of planning and management. The national park monitoring scheme, which is made for the dynamic control of the protected objects and the improvement of the functional zoning, is the important basis for improvement or revision of the functional zoning of national parks. The eco-environment, the biodiversity conservation, the community development, and the visitors experience and education have become the indicators for monitoring national parks in different countries and are the most important factors for the functional zoning of national parks.

It is necessary to study the scientific functional zoning of an area, the development pattern with clear functions and complementary advantages, the policies of exploitation and protection of national parks, and the development and protection based on the functional zoning. Taking the Three-River-Source National Park (TNP) as the study area, this paper establishes an evaluation system for the functional zoning to analyze the features of ecosystem services, potential distribution of key species habitats, ecological sensitivity, and ecological resilience in the study area, in order to provide support for management of national parks.

\section{Introduction of the study area}

TNP covers an area of 123,100 $\mathrm{km}^{2}$, including Zhiduo County, Qumalai County, Maduo County, Zaduo County and Hoh Xil nature reserve, with a total of 12 villages and towns and 53 administrative villages (Figure 1). Located in the hinterland of the Tibetan Plateau, this park is dominated by mountains and canyons. The terrain is complex with an average altitude of $4500 \mathrm{~m}$ or more. The average annual temperature is between $-5.6-7.8^{\circ} \mathrm{C}$ and the cold season here lasts for 7 months. The average annual runoff volume of the source of the three rivers, namely, the Yangtze River, the Yellow River and the Lancang River, is 49.9 billion $\mathrm{m}^{3}$, of which, the Yangtze River is 18.4 billion $\mathrm{m}^{3}$, the Yellow River 20.8 billion $\mathrm{m}^{3}$, the Lancang River 10.7 billion $\mathrm{m}^{3}$, and the water quality is excellent. There are many lakes, including freshwater lakes and brackish water lakes. The alpine meadows and alpine grasslands are widely distributed with a simple flora. There are 50 species of animals under special protection, including 15 first-class national protected animals such as Panthera uncia, P. pardus, 
Equus kiang, Pantholops hodgsonii, Bos mutus, Przewalskium albirostris, Moschus sifanicus, Grus nigricollis, Aquila chrysaetos, Haliaeetus albicilla, H. leucoryphus, Aquila heliaca, Gypaetus barbatus, Tetrastes sewerzowi, Tetraophasis obscurus and 35 second-class national protected animals.

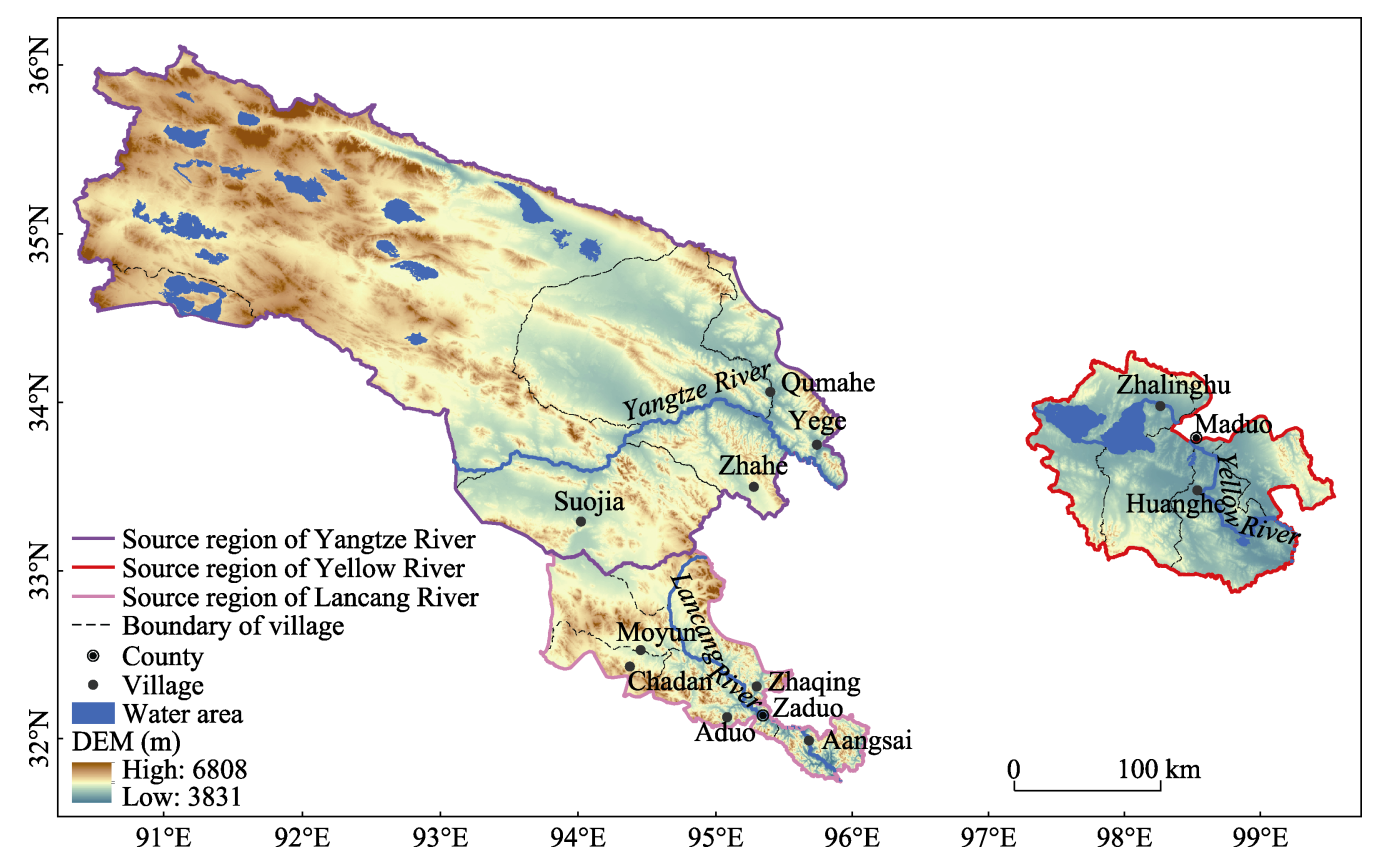

Figure 1 Location of the Three-River-Source National Park, China

\section{Research methods}

\subsection{Data source}

The data mainly include: (1) data of land use, which is extracted by the interpretation of man-machine interaction from remote sensing images combined with the map of land use status, the digital elevation model with a resolution of $30 \mathrm{~m} \times 30 \mathrm{~m}$ and the spectroscopic data of ground features through field measurement. (2) Data of climate, which comes from the data center of China Meteorological Administration and includes the data of daily average temperature, relative humidity, precipitation and sunshine duration. The observations of precipitation from meteorological stations in and around the study area are processed wit $h$ the aid of ANUSPLIN (Hutchinson and Xu, 2013) to draw the spatial distribution map of precipitation with a resolution of $1 \mathrm{~km} \times 1 \mathrm{~km}$; the potential evapotranspiration rate $\left(\mathrm{ET}_{0}\right)$ observed from each meteorological station is calculated based on the Penman-Monteith model revised by United Nations Food and Agriculture Organization (Allan et al., 1998), and it is processed with the aid of ANUSPLIN to draw the spatial distribution map with a resolution of $1 \mathrm{~km} \times 1 \mathrm{~km}$. (3) Data of soil, which comes from the rasterization of 1:1,000,000 soil spatial attribute data. (4) Data of net primary productivity (NPP), which comes from the natural vegetation NPP model created by Zhou et al. (1998). (5) Data of distribution of key species, which is provided by TNP Administration. 


\subsection{Establishment of evaluation index system}

The evaluation index system is an important mean for functional zoning and directly affects the process and results. On the basis of the previous researches (Nandy et al., 2015; Zafar et al., 2011; Wang, 2000), the index system of functional zoning of TNP (Table 1) is proposed, and 13 indexes are selected to evaluate the ecosystem services, potential distribution of key species habitats, ecological sensitivity and ecological resilience in the study area.

The evaluation of ecosystem services contributes to determine the important areas of ecological protection, and provides an important basis for determining the ecological functions and protecting the eco-environment. Three indicators, namely, the carbon sequestration, water conservation and soil conservation are selected to evaluate the ecosystem services (Lai et al., 2013). Ecological sensitivity is the ecosystem's ability of anti-interference when it is affected by multiple factors. In an area with high sensitivity, the ecosystem is liable to be damaged and it is the focus of eco-environmental protection and restoration and human activities are limited or prohibited in this area. Four indicators, namely, the vegetation, rivers and lakes, topography and soil erosion are selected for a comprehensive evaluation (Wei et al., 2015; MWRC, 2008). Ecological resilience refers to the ecosystem's ability of self-regulation and self-recovery, which is related to the structure and composition of the eco-environment. The ecological resilience of the Three-River-Source region is mainly reflected in two aspects: net primary productivity of vegetation and soil organic matter.

The Three-River-Source region, which is the key area for protecting the wild animals in China, has a large number of animals under national special protection. Therefore it is important to determine the spatial distribution pattern of species' habitats for the reasonable and effective protection. According to the IUCN Red List, China Species Red List and List of Wildlife under Special State Protection, 15 species of 4 groups are selected for analysis (The species were classified as critically endangered (CR), endangered (EN) and vulnerable (VU) on the list, as well as regionally representative.), including 5 species of carnivores (Panthera uncia, Ursus arctos, Vulpes ferrilata, Martes foina and Lutra lutra), 5 species of ungulates (Gervus albirostris, Bos mutus, Pantholops hodgsonii, Equus kiang and Pseudois nayaur), 3 species of birds (Grus nigricollis, Gypaetus barbatus and Anser indicus) and 2 species of fishes (Platypharodon extremus and Schizothorax lissolabiatus). Based on the distribution points data of 15 species and 9 environment variables (altitude, gradient, slope direction, temperature, rainfall, distance from water, surface coverage type, roads, residential areas), the habitat spatial distribution of each species was simulated and analyzed using MaxEnt species distribution model. All kinds of potential species habitats were calculated from weighted-overlay classification with optimum habitats on the maximized Kappa value for the habitat suitability index (Hirzel et al., 2006; Qi et al., 2011).

\subsection{Methods of evaluation}

First, in order to carry out the space superposition for different evaluation indexes, with the help of GIS, each index layer is unified into one coordinate system and projection system, and the size of the grid of each index layer is $30 \mathrm{~m} \times 30 \mathrm{~m}$. Secondly, according to the ecological importance, the attribute data of evaluation indexes is graded into 4 levels (Table 1). Thirdly, the weight of each index is determined through the analytic hierarchical process and expert scoring method (Deng et al., 2012). Finally, each evaluation index is assigned 
Table 1 Evaluation index system and classification for functional zoning of the Three-River-Source National Park

\begin{tabular}{|c|c|c|c|c|c|c|c|c|c|}
\hline \multirow{2}{*}{ Category } & \multirow{2}{*}{ Weight } & \multirow{2}{*}{ Indicator } & \multirow{2}{*}{ Weight } & \multirow{2}{*}{ Unit } & \multicolumn{4}{|c|}{ Classification assignment } & \multirow{2}{*}{$\begin{array}{l}\text { Methods and } \\
\text { sources }\end{array}$} \\
\hline & & & & & 1 & 2 & 3 & 4 & \\
\hline \multirow{3}{*}{$\begin{array}{l}\text { Ecosys- } \\
\text { tem } \\
\text { services }\end{array}$} & \multirow{3}{*}{0.35} & $\begin{array}{l}\text { Quantity of } \\
\text { water conserva- } \\
\text { tion }\end{array}$ & 0.51 & $\mathrm{~mm}$ & $<200$ & $200-300$ & $300-400$ & $>400$ & $\begin{array}{l}\text { InVEST } \\
\text { model; Lai et } \\
\text { al., } 2013\end{array}$ \\
\hline & & $\begin{array}{l}\text { Quantity of soil } \\
\text { conservation }\end{array}$ & 0.31 & $\mathrm{t} / \mathrm{ha}$ & $0-100$ & $100-200$ & $200-400$ & $>400$ & $\begin{array}{l}\text { USLE; Lai et } \\
\text { al., } 2013\end{array}$ \\
\hline & & $\begin{array}{l}\text { Quantity of } \\
\text { carbon seques- } \\
\text { tration }\end{array}$ & 0.18 & $\mathrm{gC} / \mathrm{m}^{2}$ & $<50$ & $50-100$ & $100-200$ & $>200$ & $\begin{array}{l}\text { Photosynthesis } \\
\text { equation; Lai } \\
\text { et al., } 2013\end{array}$ \\
\hline \multirow{4}{*}{$\begin{array}{l}\text { Ecologi- } \\
\text { cal sensi- } \\
\text { tivity }\end{array}$} & \multirow{4}{*}{0.2} & $\begin{array}{l}\text { Vegetation } \\
\text { coverage }\end{array}$ & 0.36 & $\%$ & $<5$ & $5-10$ & $10-20$ & $>20$ & $\begin{array}{l}\text { NDVI; Wei et } \\
a l ., 2015\end{array}$ \\
\hline & & $\begin{array}{l}\text { Buffer zone of } \\
\text { rivers and lakes }\end{array}$ & 0.29 & $\mathrm{~m}$ & $>100$ & $100-50$ & $50-1$ & $<1$ & $\begin{array}{l}\text { Wei et al., } \\
2015\end{array}$ \\
\hline & & Elevation & 0.18 & $\mathrm{~m}$ & $3500-4000$ & $4000-4500$ & $4500-5000$ & $5000-7000$ & $\begin{array}{l}\text { DEM; Wei } \\
\text { et al., } 2015\end{array}$ \\
\hline & & $\begin{array}{l}\text { Soil erosion } \\
\text { intensity }\end{array}$ & 0.17 & - & $<2500$ & $2500-5000$ & $5000-8000$ & $>8000$ & MWRC, 2008 \\
\hline \multirow{2}{*}{$\begin{array}{l}\text { Ecologi- } \\
\text { cal resil- } \\
\text { ience }\end{array}$} & \multirow{2}{*}{0.15} & $\begin{array}{l}\text { Net primary } \\
\text { productivity of } \\
\text { vegetation }\end{array}$ & 0.50 & $\mathrm{~g} / \mathrm{m}^{2}$ & $<200$ & $200-400$ & $400-800$ & $>800$ & $\begin{array}{l}\text { NPP model; } \\
\text { Zhou et al., } \\
1998\end{array}$ \\
\hline & & $\begin{array}{l}\text { Soil organic } \\
\text { matter }\end{array}$ & 0.50 & $\%$ & $<1$ & $1-3$ & $3-5$ & $>5$ & $\begin{array}{l}\text { National soil } \\
\text { spatial attrib- } \\
\text { ute data }\end{array}$ \\
\hline \multirow{4}{*}{$\begin{array}{l}\text { Potential } \\
\text { distribu- } \\
\text { tion of } \\
\text { key } \\
\text { species } \\
\text { habitats }\end{array}$} & \multirow{4}{*}{0.3} & $\begin{array}{l}\text { Potential dis- } \\
\text { tribution of } \\
\text { carnivores }\end{array}$ & 0.33 & - & 0 & - & - & 1 & \multirow{4}{*}{$\begin{array}{l}\text { MaxEnt } \\
\text { model; Hirzel } \\
\text { et al., 2006; } \\
\text { Qi et al., } 2011\end{array}$} \\
\hline & & $\begin{array}{l}\text { Potential dis- } \\
\text { tribution of } \\
\text { ungulates }\end{array}$ & 0.27 & - & 0 & - & - & 1 & \\
\hline & & $\begin{array}{l}\text { Potential dis- } \\
\text { tribution of } \\
\text { birds }\end{array}$ & 0.24 & - & 0 & - & - & 1 & \\
\hline & & $\begin{array}{l}\text { Potential dis- } \\
\text { tribution of } \\
\text { fishes }\end{array}$ & 0.16 & - & 0 & - & - & 1 & \\
\hline
\end{tabular}

with a value through the comprehensive index method ( $\mathrm{Li}$ et al., 2005) and then processed via the weighted overlay analysis. The results of evaluation are graded into 4 levels by using Natural Breaks clustering method in ArcGIS, namely, the general area, the less important area, the important area and the most important area.

\section{Results}

\subsection{Analysis on ecological characteristics}

The ecological characteristics of TNP (Figures 2 and 3) are evaluated by the evaluation index system (Table 1) of functional zoning. The spatial distribution pattern of the ecosystem services in the park is obvious (Figure 2a), increasing gradually from the northwest to the southeast. The ecological sensitivity of the park is high (Figure 2b), and the proportion of areas with very high sensitivity and high sensitivity is relatively large, accounting for $79.64 \%$ of the total area of the park. The areas with very high ecological resilience and high 
resilience are mainly distributed in the Source Region of the Yellow River, the Source Region of the Lancang River and the east of the Source Region of the Yangtze River (Figure 2c). The area with low ecological resilience is mainly distributed in Hoh Xil, covering an area of $39,600 \mathrm{~km}^{2}$ and accounting for $32.18 \%$ of the total area of the park. The central and southern parts of the Source Region of the Yangtze River and the eastern part of Source Region of the Lancang River are the most important habitats of species (Figure 2d).
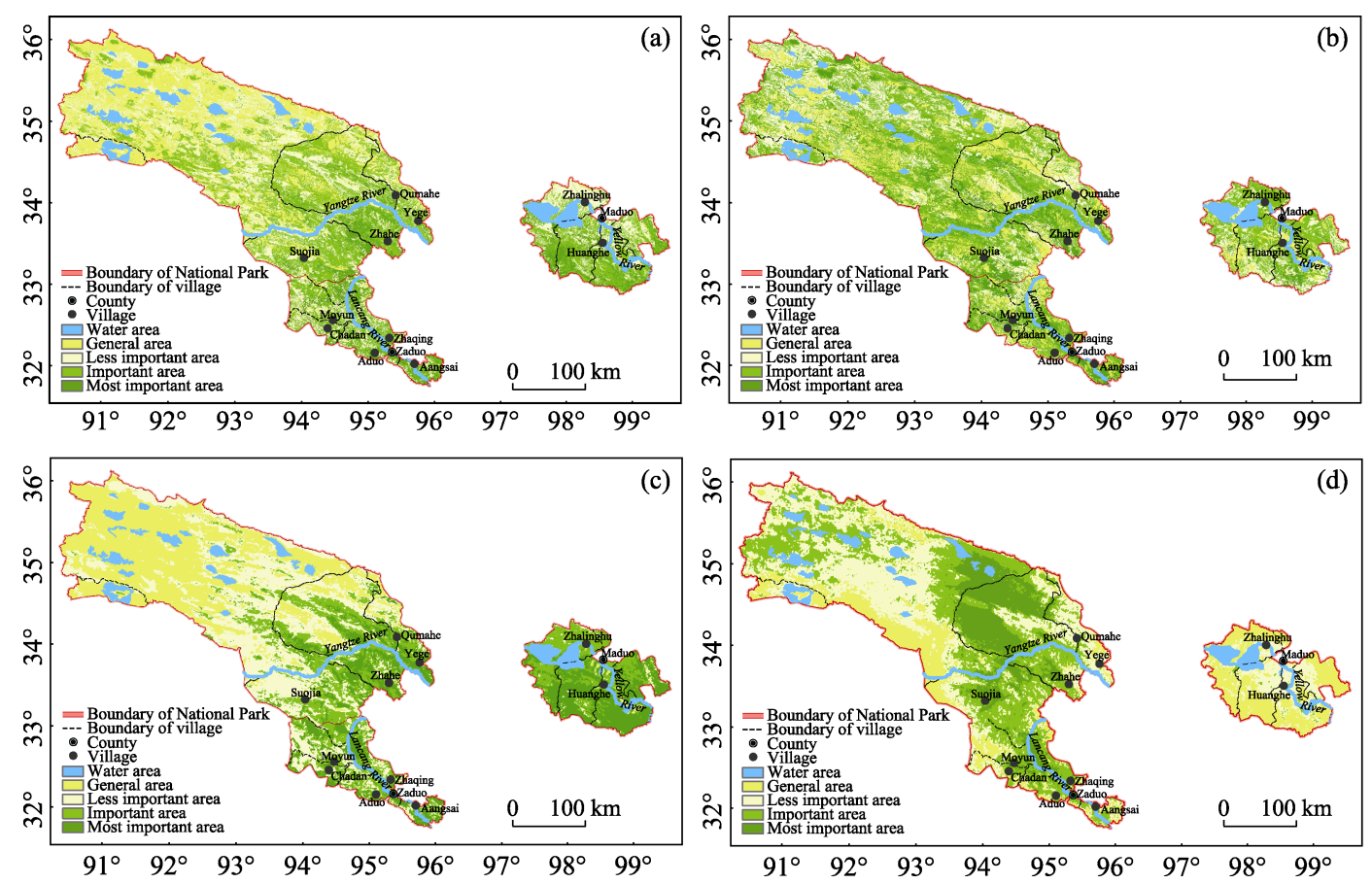

Figure 2 The spatial distribution of each category of indexes in the Three-River-Source National Park (a. Ecosystem services; b. Ecological sensitivity; c. Ecological resilience; d. Potential habitats of key species)

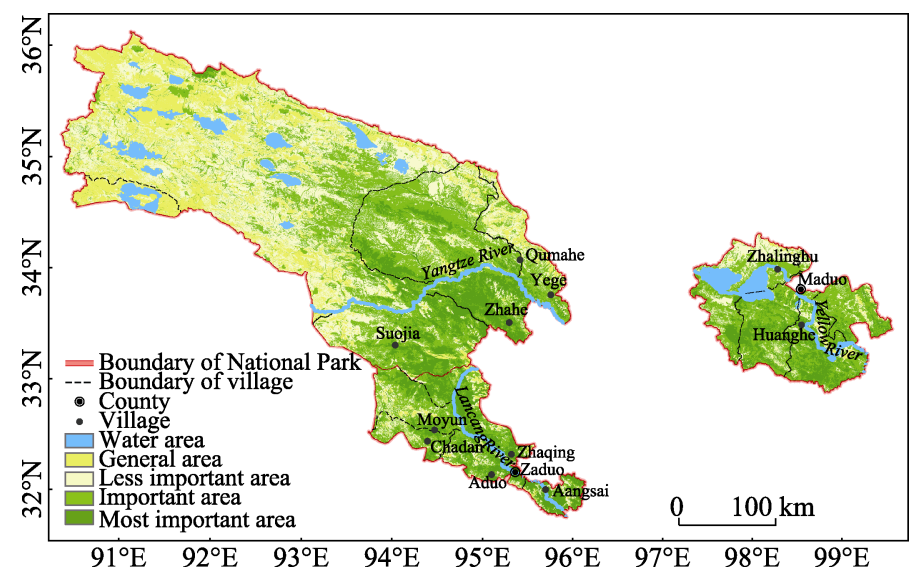

Figure 3 Comprehensive assessment of the Three-River-Source National Park 


\subsection{Functional zoning of TNP}

(1) The plan for first-level functional zoning

On the basis of the functional zoning of the park, according to the management requirements of various kinds of protected areas, and combining with the results of evaluation of current situation, the park is divided into the core conservation area, the ecological restoration area and the traditional utilization area based on the targets of ecosystem services and protection (Table 2 and Figure 4). The differential measures of management and control are carried out to achieve the scientific and rational layout and sustainable utilization of ecology, production and living space. The functional zones should be under the dynamic management based on the status of protection and recovery and the regular monitoring and evaluation. The core conservation area should be gradually expanded, the traditional utilization area should be gradually shrunk and the ecological restoration area should be properly adjusted.

The core conservation area covers an area of $90,500 \mathrm{~km}^{2}$, accounting for $73.5 \%$ of the total area of the park. This area is a basic ecological space for maintaining the functions of a natural ecosystem and taking more strict measures of protection. The core area and buffer zone of the reserve are baselines, linked up to the borders of natural heritage sites, the core areas of the international and national important wetlands, the national protected area of aquaculture genetic resources and the national scenic area of water conservancy. It also relates to the designation of important habitats of wild animals. The traditional utilization area with a generally stable ecological situation is outside the core conservation area of the park. This area is the traditional space for the local herdsmen's life and production and the buffer zone for taking in the population and industries transferred from the core conservation area. The area is about $26,700 \mathrm{~km}^{2}$, accounting for $21.67 \%$ of the total area of the park. The medium and severely degraded grassland in the traditional utilization area is designated as the ecological restoration area which covers an area of $6000 \mathrm{~km}^{2}$, accounting for $4.83 \%$ of the total area of the park. In this area, the restoration measures of degraded grassland, desertification, black soil land, mining area and soil erosion are taken.

(2) The plan for second-level functional zoning

In order to protect the authenticity of the ecological process, on the basis of ecosystem services, the core conservation area is divided into special protection area, area of rivers, lakes and wetlands and natural conservation area for the important ecological functions, such as water conservation, soil and water conservation and important habitats of animals and plants. The special protection area is an important habitat for rare and endangered species such as Panthera uncia and Pantholops hodgsonii, as well as an important protected area for aquaculture genetic resources. The area of rivers, lakes and wetlands includes the important rivers, lakes and marshes, which is an important water conservation area. The natural conservation area is a special protection area outside the core conservation area and the area of rivers, lakes and wetlands. This area with important ecological services and fragile ecosystem is the important habitat of wildlife such as Bos mutus, Equus kiang and Przewalskium albirostris.

According to the causes of grassland degradation, and combining with the limits of the right to grassland contractual management and the progress of first-stage project and second-stage project of the Three-River-Source region ecological protection, the ecological restoration area is divided into the restoration area of desertification which is a large deserti- 
fied area, the restoration area of black soil land which is a degraded grassland of black soil type and the restoration area of enclosure which is an area other than the desertification and black soil land.

According to the needs of the ecological animal husbandry, the distribution of villages and the limits of the right to grassland contractual management, the traditional utilization area is divided into the grazing prohibition area, the forage-livestock balance area and the regulatory area of construction land. The medium and severe degraded grasslands are prohibited from grazing by stages and under the dynamic management; the non-degraded and lightly degraded grasslands are under the management of forage-livestock balance (Table 2 and Figure 5).

Table 2 Functional zoning of the Three-River-Source National Park

\begin{tabular}{|c|c|c|c|c|c|}
\hline Region & Area $\left(\mathrm{km}^{2}\right)$ & First-level zone & Area $\left(\mathrm{km}^{2}\right)$ & Second-level zone & Area $\left(\mathrm{km}^{2}\right)$ \\
\hline \multirow{9}{*}{$\begin{array}{l}\text { Source Region of } \\
\text { the Yangtze River }\end{array}$} & \multirow{9}{*}{90321.49} & & & Special protection area & 8142.56 \\
\hline & & $\begin{array}{l}\text { Core conservation } \\
\text { area }\end{array}$ & 75546.27 & Area of rivers, lakes and wetlands & 4060.50 \\
\hline & & & & Natural conservation area & 63343.21 \\
\hline & & & & Restoration area of desertification & 261.82 \\
\hline & & $\begin{array}{l}\text { Ecological restora- } \\
\text { tion area }\end{array}$ & 1504.76 & Restoration area of black soil land & 104.76 \\
\hline & & & & Restoration area of enclosure & 1138.18 \\
\hline & & & & Grazing prohibition area & 5219.24 \\
\hline & & $\begin{array}{l}\text { Traditional utiliza- } \\
\text { tion area }\end{array}$ & 13270.46 & Forage-livestock balance area & 8051.22 \\
\hline & & & & Regulatory area of construction land & - \\
\hline \multirow{9}{*}{$\begin{array}{l}\text { Source Region of } \\
\text { the Yellow River }\end{array}$} & \multirow{9}{*}{19083.13} & & & Special protection area & 1173.30 \\
\hline & & $\begin{array}{l}\text { Core conservation } \\
\text { area }\end{array}$ & 8602.87 & Area of rivers, lakes and wetlands & 1075.53 \\
\hline & & & & Natural conservation area & 6354.05 \\
\hline & & & & Restoration area of desertification & 484.47 \\
\hline & & $\begin{array}{l}\text { Ecological restora- } \\
\text { tion area }\end{array}$ & 2445.43 & Restoration area of black soil land & 25.98 \\
\hline & & & & Restoration area of enclosure & 1934.98 \\
\hline & & & & Grazing prohibition area & 2043.57 \\
\hline & & $\begin{array}{l}\text { Traditional utiliza- } \\
\text { tion area }\end{array}$ & 8034.82 & Forage-livestock balance area & 5991.26 \\
\hline & & & & Regulatory area of construction land & - \\
\hline \multirow{8}{*}{$\begin{array}{l}\text { Source Region of } \\
\text { the Lancang River }\end{array}$} & \multirow{8}{*}{13736.19} & \multirow{2}{*}{$\begin{array}{l}\text { Core conservation } \\
\text { area }\end{array}$} & \multirow{2}{*}{6357.58} & Special protection area & 4376.47 \\
\hline & & & & Natural conservation area & 1981.11 \\
\hline & & \multirow{3}{*}{$\begin{array}{l}\text { Ecological restora- } \\
\text { tion area }\end{array}$} & \multirow{3}{*}{2000.14} & Restoration area of desertification & 35.46 \\
\hline & & & & Restoration area of black soil land & 83.22 \\
\hline & & & & Restoration area of enclosure & 1881.46 \\
\hline & & \multirow{3}{*}{$\begin{array}{l}\text { Traditional utiliza- } \\
\text { tion area }\end{array}$} & \multirow{3}{*}{5378.47} & Grazing prohibition area & 1611.99 \\
\hline & & & & Forage-livestock balance area & 3766.48 \\
\hline & & & & $\begin{array}{l}\text { Regulatory area of construction } \\
\text { land }\end{array}$ & - \\
\hline
\end{tabular}




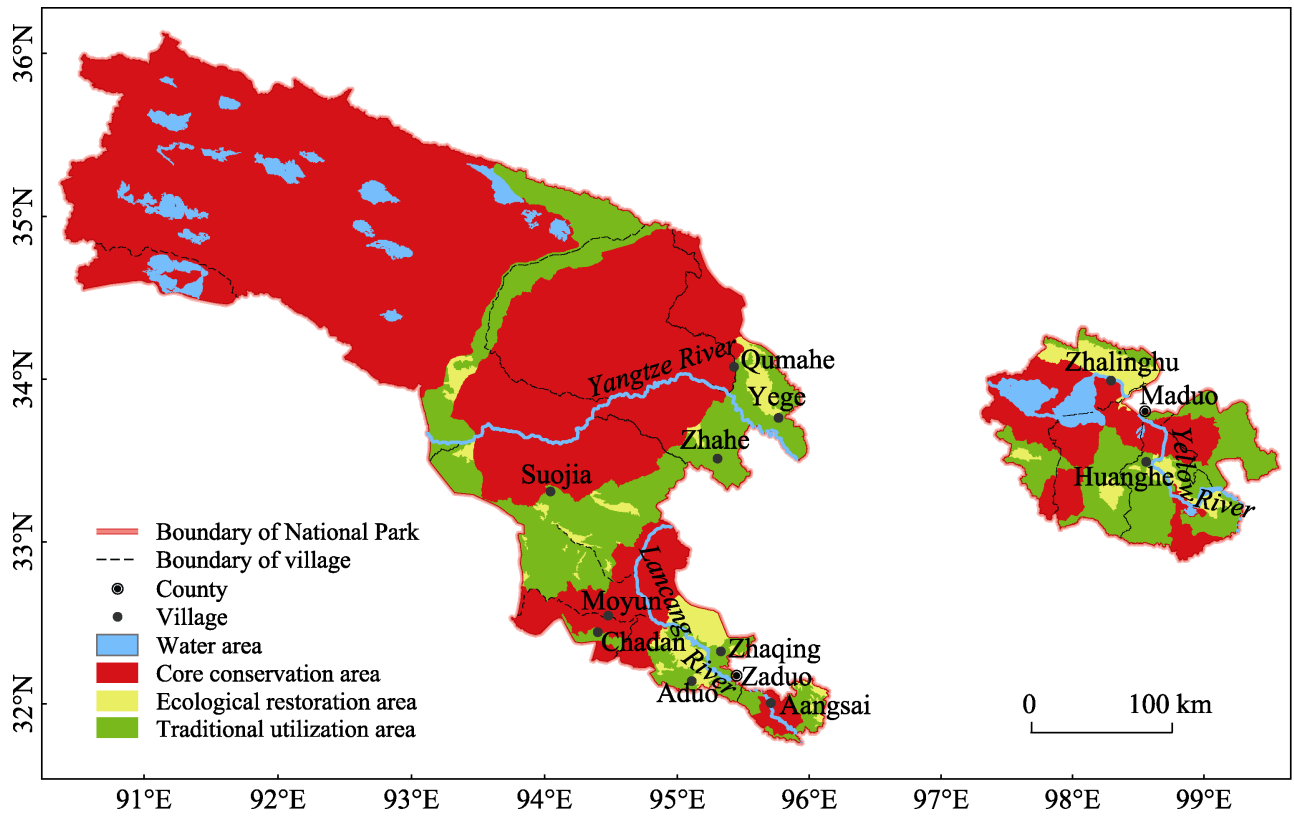

Figure 4 The first-level functional zoning of the Three-River-Source National Park

\subsection{Space management of TNP}

On the basis of the concepts of overall protection and systematic restoration, the first-level functional zones should have definite management targets and the second-level functional zones should implement the management measures. The management targets and measures of each functional zone are specified in Table 3.

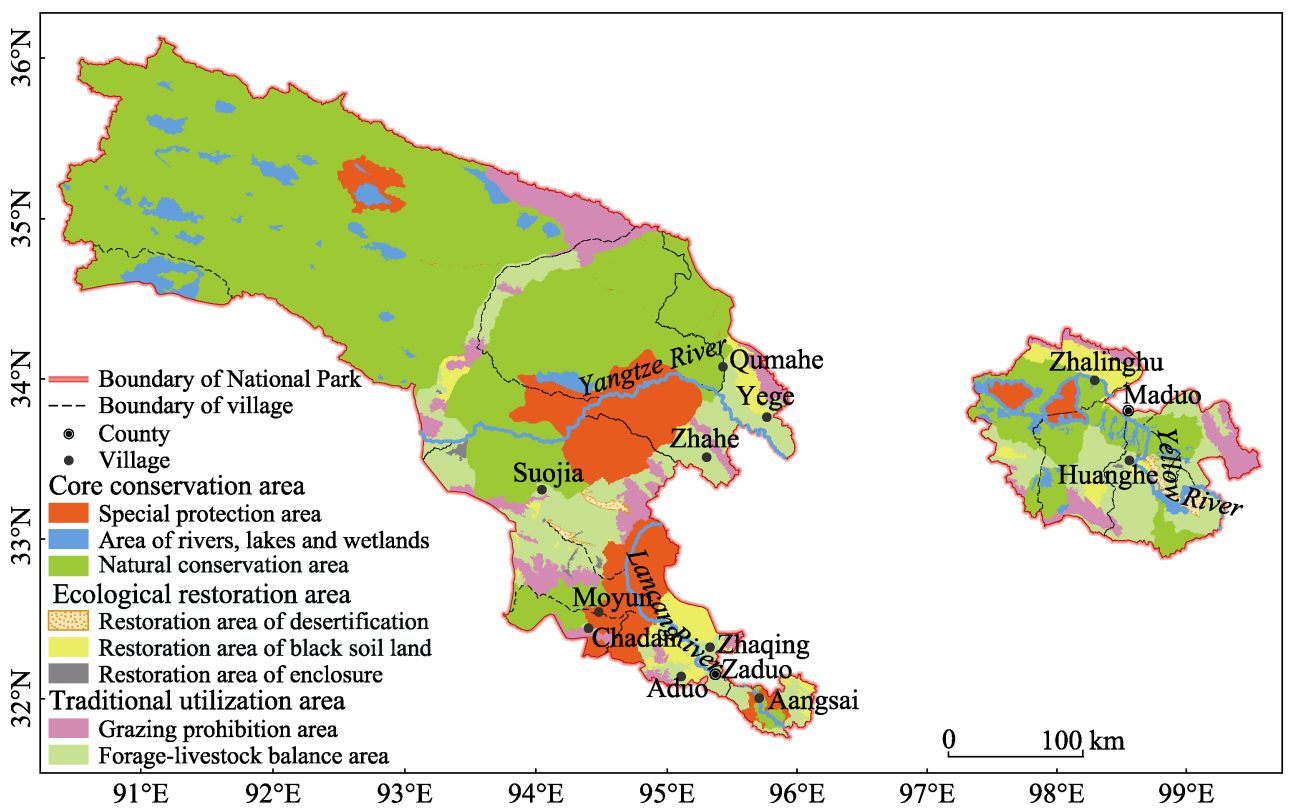

Figure 5 The second-level functional zoning of the Three-River-Source National Park 
Table 3 Space management of the Three-River-Source National Park

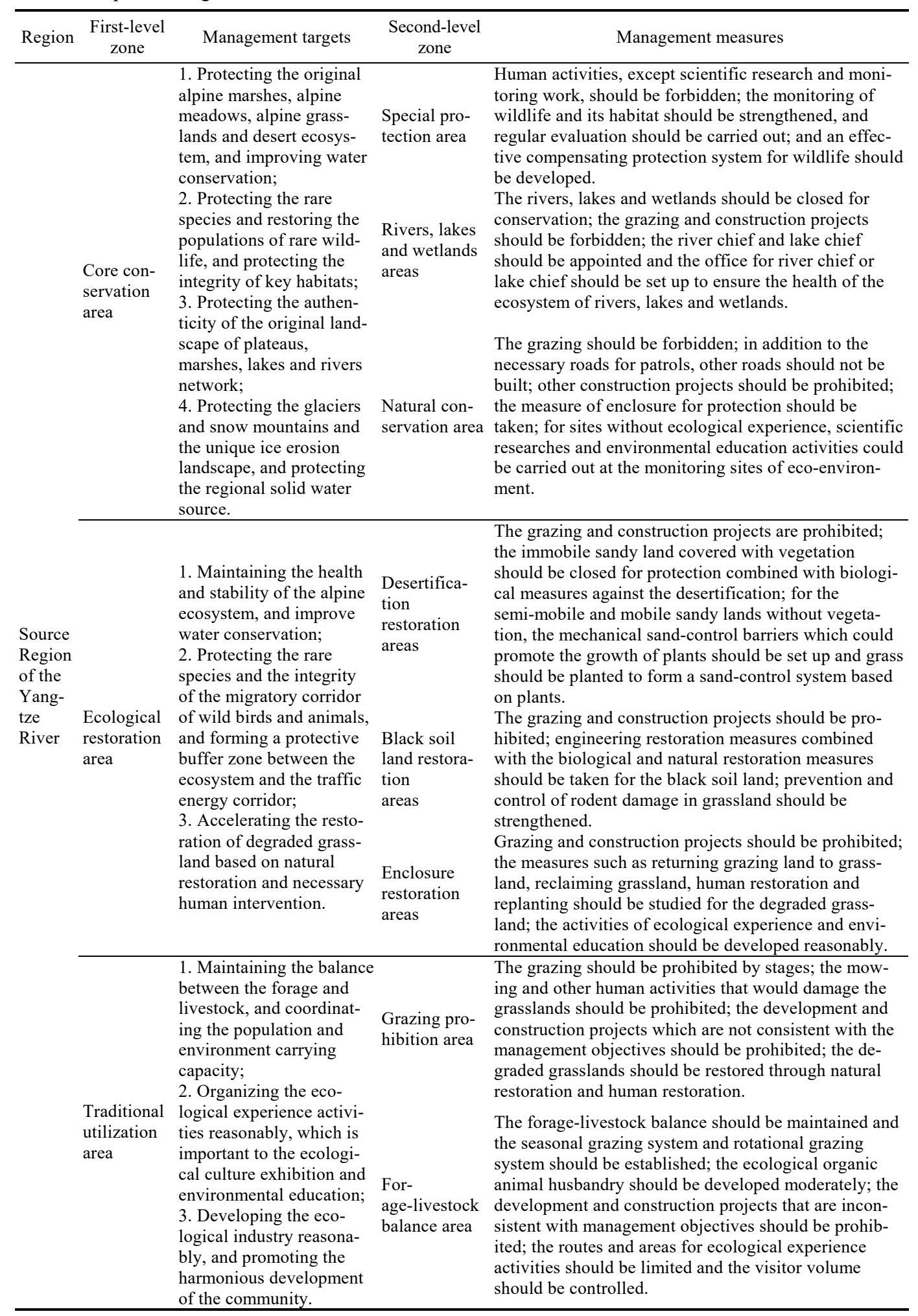




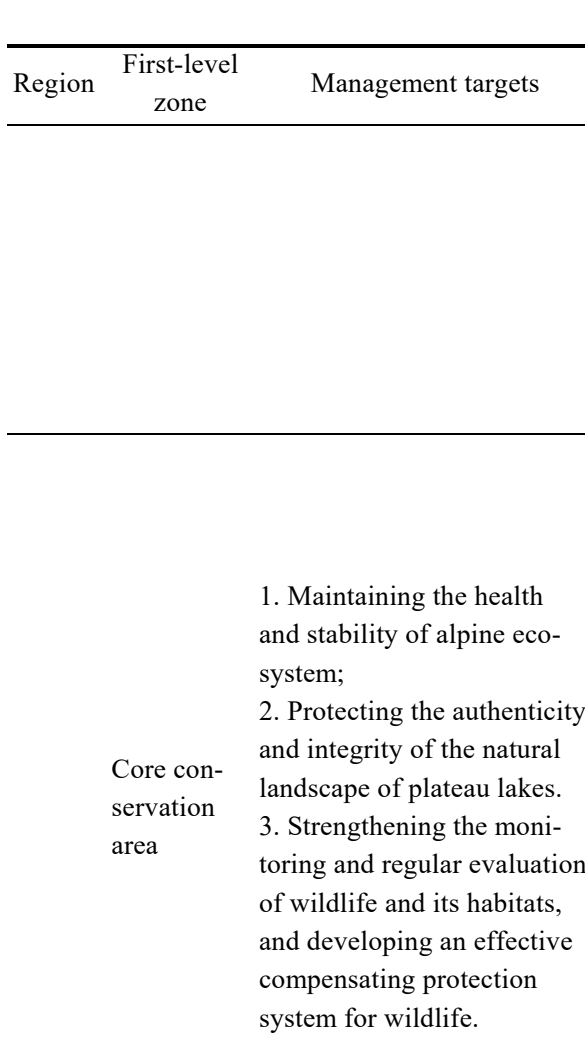

(Continued)

Construction
regulatory

area

\section{Special pro-}

tection area

\section{Rivers, lakes}

and wetlands

areas

servation area

The land use for urban and rural construction projects should be under strict management, and the scale and layout of land for urban and rural construction should be controlled; the roads should be strictly planned and built, and the animal corridors should be set for ecological restoration; franchising is allowed such as catering and entertainment services.

Human activities except the scientific research and monitoring work should be forbidden; monitoring of wildlife and its habitat should be strengthened, and regular evaluation should be carried out.

The rivers, lakes and wetlands should be closed for conservation; the grazing and construction projects should be forbidden; the river chief and lake chief should be appointed and the office for river chief or lake chief should be set up to ensure the health of the ecosystems of rivers, lakes and wetlands; fishing should be prohibited in the long term.

Grazing should be forbidden; in addition to the necessary roads for patrol, other roads should not be built; other construction projects should be prohibited; the measures of enclosure for conservation should be studied; for sites without the ecological experience, scientific researches and environmental education activities could be carried out at the monitoring sites of eco-environment.

Source

Region

of the

Yellow

River

1. Accelerating the restoration of degraded grassland

Ecological based on the natural restorarestoration area tion, and combination of necessary manual intervention.

2. Improving the water conservation and biodiversity.
Grazing and construction projects should be prohibited; immobile sandy land covered with vegetation should be closed for conservation and biological

Desertification measures against desertification should be taken; for restoration semi-mobile and mobile sandy lands without vegeareas tation, mechanical sand-control barriers which could promote the growth of plants should be set up and grass should be planted to form a sand-control system based on plants.

Grazing and construction projects should be prohibited; engineering restoration measures combined

Black soil land restoration areas with biological and natural restoration measures should be studied for the black soil lands; prevention and control of rodent damage in grassland should be strengthened.

Grazing and construction projects should be prohibited; measures such as returning grazing land to

Enclosure grassland, reclaiming grassland, human restoration restoration and replanting should be studied for the degraded area grassland; the activities of ecological experience and environmental education should be developed reasonably. 
(Continued)

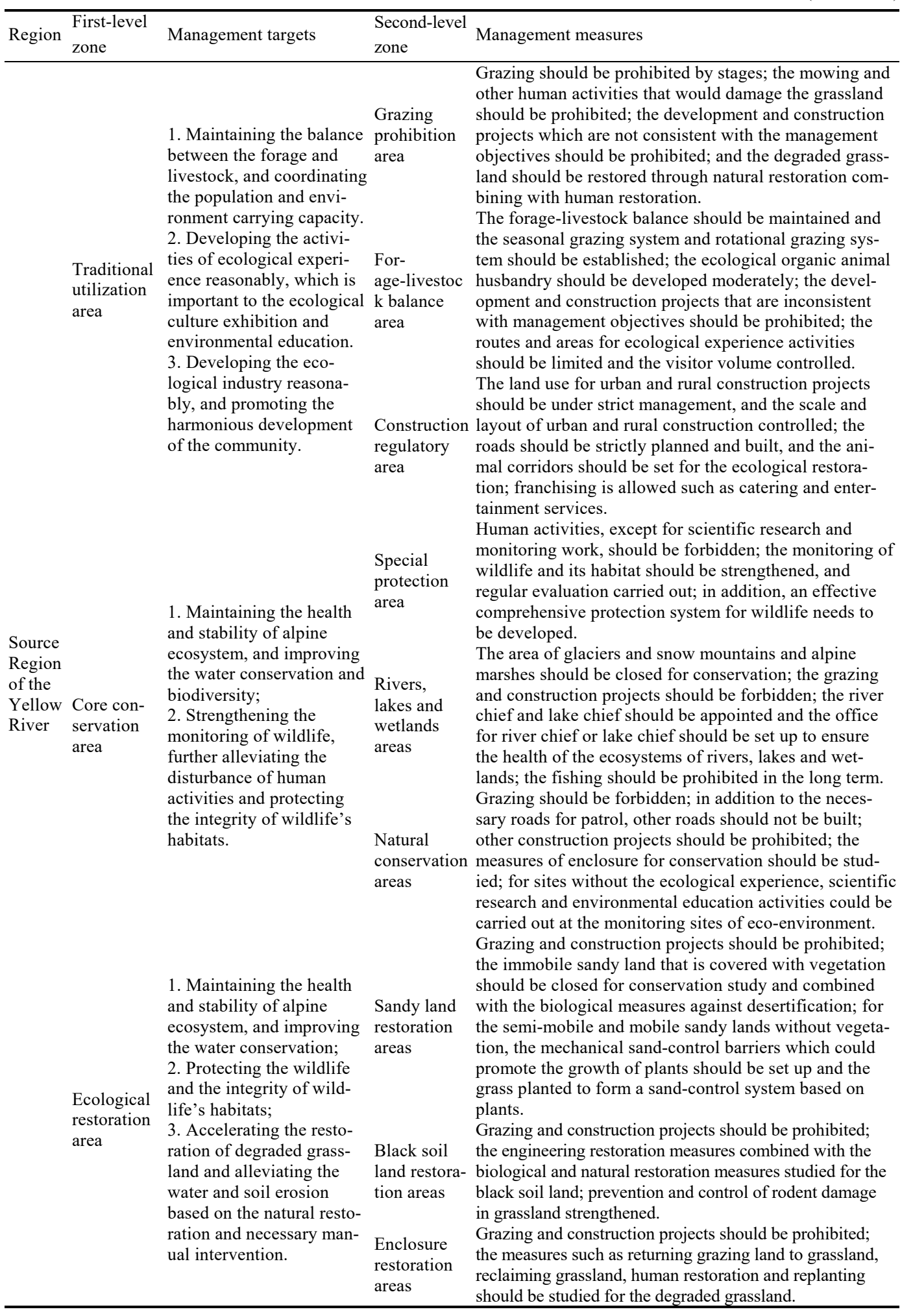

(To be continued on the next page) 


\begin{tabular}{|c|c|c|c|c|}
\hline Region & $\begin{array}{l}\text { First-level } \\
\text { zone }\end{array}$ & Management targets & $\begin{array}{l}\text { Second- } \\
\text { level zone }\end{array}$ & Management measures \\
\hline \multirow{3}{*}{$\begin{array}{l}\text { Source } \\
\text { Region } \\
\text { of the } \\
\text { Lan- } \\
\text { cang } \\
\text { River }\end{array}$} & \multirow{3}{*}{$\begin{array}{l}\text { Traditional } \\
\text { utilization } \\
\text { area }\end{array}$} & \multirow{3}{*}{$\begin{array}{l}\text { 1. Maintaining the balance } \\
\text { between the forage and } \\
\text { livestock, and coordinating } \\
\text { the population and envi- } \\
\text { ronment carrying capacity. } \\
\text { 2. Developing the activities } \\
\text { of ecological experience } \\
\text { reasonably, which is impor- } \\
\text { tant to the ecological culture } \\
\text { exhibition and environ- } \\
\text { mental education. } \\
\text { 3. Innovating the plateau } \\
\text { ecological animal hus- } \\
\text { bandry, and promoting the } \\
\text { harmonious development of } \\
\text { the community. }\end{array}$} & $\begin{array}{l}\text { Grazing } \\
\text { prohibition } \\
\text { areas }\end{array}$ & $\begin{array}{l}\text { Grazing should be prohibited by stages; the mowing } \\
\text { and other human activities that would damage the } \\
\text { grassland should be prohibited; the development and } \\
\text { construction projects which are not consistent with the } \\
\text { management objectives should be prohibited; the de- } \\
\text { graded grassland should be restored through natural } \\
\text { restoration and human restoration. }\end{array}$ \\
\hline & & & $\begin{array}{l}\text { Forage- } \\
\text { livestock } \\
\text { balance area }\end{array}$ & $\begin{array}{l}\text { The forage-livestock balance should be maintained and } \\
\text { the seasonal grazing system and rotational grazing } \\
\text { system should be established; the ecological organic } \\
\text { animal husbandry should be developed moderately; the } \\
\text { development and construction projects that are incon- } \\
\text { sistent with management objectives should be prohib- } \\
\text { ited; the routes and areas for ecological experience } \\
\text { activities should be limited and the visitor volume } \\
\text { should be controlled. }\end{array}$ \\
\hline & & & $\begin{array}{l}\text { Construction } \\
\text { regulatory } \\
\text { areas }\end{array}$ & $\begin{array}{l}\text { The land use for urban and rural construction projects } \\
\text { should be under strict management, and the scale and } \\
\text { layout of urban and rural construction controlled; the } \\
\text { roads should be strictly planned and built, and animal } \\
\text { corridors should be set for ecological restora- } \\
\text { tion;franchising is allowed such as catering and enter- } \\
\text { tainment services. }\end{array}$ \\
\hline
\end{tabular}

Notes: The river/lake chiefs are the first responsible persons for river/lake management and protection.

\section{Conclusions and discussion}

National parks have multiple functions such as protecting and preserving natural resources; providing and enriching, visitors experience on environmental education; acting as guardians of our diverse cultural and recreational resources in order to preserve them for future generations; providing researchers the opportunities to gather and monitor data dealing with core conservation issues, ecological restoration, land, forest and water usage and conservation, wildlife and bird and their natural habitats protection, and the geology of the history of man. In addition, national parks must deal with community development, and the public relations issues that go along with the resettlement of populations, park boarders, and public concerns. A scientific functional zoning will help the protection of natural resources and balance the interests of all parties. Combining with the ecological protection, the functional zoning of national parks should focus on the status of humans in the ecosystem, especially in the evaluation index system. The human activities such as community development, visitors experience and environmental education should be considered as a whole.

At present, the methods used in functional zoning of nature reserves mainly include systematic conservation planning (Margules and Pressey, 2000), hotspot analysis (Myers, 2000), landscape suitability assessment (Chen et al., 2006), niche model method (Costa et al., 2010), vacancy analysis method (Scott and Wright, 1993), and model software such as C-plan, MARXAN, PANDA, CLUZ, and ZONATION. Different methods have different emphases on resource utilization and protection. The hotspot analysis and niche model method emphasize the protection of resources, and give less consideration to human activities and resource utilization. Systematic conservation planning, landscape suitability as- 
sessment, and vacancy analysis take resource utilization as an important factor into consideration. In the process of planning, suitable zoning methods are selected according to different types of national parks, and multiple zoning methods can be used for functional zoning of national parks at the same time. Following the principles of overall protection of ecosystem and systematic restoration, and based on comprehensive assessment of ecological conditions through comprehensive index method, this study divides the Three-River-Source National Park into first-level functional zone with definite targets of space management; and through integrating various regional plans, and combining the administrative division, boundary of river basins and boundary of determining the ownership of natural resources, the second-level zone with targets of implementation of management measures.

There are many problems in the functional zoning of nature reserves in China, such as insufficient background information, strong subjectivity, unclear concept, and poor operability (Huyan et al., 2014; Tang et al., 2017). It is necessary to strengthen the background investigation and monitoring of national parks, change the single and static pattern of functional zoning, explore and innovate the combination of qualitative and quantitative methods for functional zoning, and formulate appropriate management measures. With the partitioned management of national parks, the national park is able to give full play to ecosystem service function, and the functions of scientific research, education and recreation can be taken into account to coordinate and unify the strict protection and rational utilization.

\section{References}

Allan R G, Pereira L S, Raes D et al., 1998. Crop Evapotranspiration: Guidelines for Computing Crop Water Requirements. Irrigation and Drainage Paper, No.56. FAO, 56.

Anderson M G, 1999. Viability and spatial assessment of ecological communities in the Northern Appalachian Ecoregion (Doctoral dissertation). Durham: University of New Hampshire.

Brown G, Weber D, 2011. Public participation GIS: A new method for national park planning. Landscape and Urban Planning, 102(1): 1-15.

Chen D, 2015. The enlightenment of Taiwan National Park on the construction management of the mainland nature reserve. China Forest Products Industry, 42(5): 58-60. (in Chinese)

Chen L X, Fu B J, Zhao W W, 2006. Source-sink landscape theory and its ecological significance. Acta Ecologica Sinica, 26(5): 1444-1449. (in Chinese)

Chen Y H, Huang D, Yan S Q, 2014. Discussions on public welfare, state dominance and scientificity of national park. Scientia Geographica Sinica, 34(3): 257-264. (in Chinese)

Costa G C, Nogueira C, Machado R B et al., 2010. Sampling bias and the use of ecological niche modeling in conservation planning: A field evaluation in a biodiversity hotspot. Biodiversity \& Conservation, 19(3): 883-899.

Deng X, Li J M, Zeng H J et al., 2012. Research on computation methods of AHP weight vector and its applications. Mathematics in Practice and Theory, 42(7): 93-100. (in Chinese)

Dilsaver L M, 1994. America's National Park System: The Critical Documents. Lanham MD: Rowman \& Littlefield.

Groves C R, Jensen D B, Valutis L L et al., 2002. Planning for biodiversity conservation: Putting conservation science into practice. Bioscience, 52(6): 499-512.

Hirzel A H, Le L G, Helfer V et al., 2006. Evaluating the ability of habitat suitability models to predict species presences. Ecological Modelling, 199: 142-152.

Huang L L, Zhu Q, Chen T, 2007. Comparison of zoning models in protected natural areas overseas and its enlightenment. Tourism Tribune, 22(3): 18-25. (in Chinese) 
Hutchinson M F, Xu T B, 2013. ANUSPLIN Version 4.4 User Guide. Centre for Resource and Environmental Studies, the Australian National University, Canberra.

Huyan J Q, Xiao J, Yu B et al., 2014. Research progress in function zoning of nature reserves in China. Acta Ecologica Sinica, 34, 6391-6396. (in Chinese)

Lai M, Wu S H, Dai E F et al., 2013. The indirect value of ecosystem services in the Three-River Headwaters Region. Journal of Natural Resources, 28(1): 38-50. (in Chinese)

Li Y L, Zhu B L, Wang L et al., 2005. Designing and application of comprehensive index method based ecological environment quality comprehensive evaluation system. Science of Surveying and Mapping, 30(1): 89-91. (in Chinese)

Margules C R, Pressey R L, 2000. Systematic conservation planning. Nature, 405(6783): $243-253$.

Ministry of Water Resources of the People's Republic of China (MWRC), 2008. Standards for Classification and Gradation of Soil Erosion SL 190-2007. Beijing: China Water Power Press, 3-12. (in Chinese)

Myers N, 2000. Biodiversity hotspots for conservation priorities. Nature, 403(6772): 853-858.

Nandy S, Singh C, Das K K et al., 2015. Environmental vulnerability assessment of eco-development zone of Great Himalayan National Park, Himachal Pradesh, India. Ecological Indicators, 57: 182-195.

National Park Service (NPS), 2009. General Management Planning Dynamic Sourcebook. Retrieved from https://parkplanning.nps.gov/files/GMPSourcebook/GMPSourcebook_Dec2009ver2.2.pdf.

Price M F, 1983. Management planning in the sunshine area of Canada's Banff National Park. Parks, 7: 6-10.

Puhakka R, Saarinen J, 2013. New role of tourism in national park planning in Finland. Journal of Environment and Development, 22(4): 411-434.

Qi Z X, Xu W H, Xiong X Y et al., 2011. Assessment of potential habitat for Ursusthibetanus in the Qinling Mountains. Biodiversity Science, 19(3): 343-352. (in Chinese)

Scott D, Malcolm J R, Lemieux C, 2002. Climate change and modelled biome representation in Canada's national park system: Implications for system planning and park mandates. Global Ecology Biogeography, 11: $475-484$.

Scott J M, Wright R G, 1993. Gap analysis: A geographical approach to protection of biological diversity. Wildlife Monographs, 57(4): 1-41.

Tang F L, Wang M J, Li G Q, 2017. Discussion on zoning for national park function. Forestry Construction, 6: 1-7. (in Chinese)

Wang W Z, 2000. National Park. Beijing: China Forestry Publishing House. (in Chinese)

Wei J, Guo Y M, Sun L et al., 2015. Evaluation of ecological environment vulnerability for Sanjiangyuan area. Chinese Journal of Ecology, 34(7): 1968-1975. (in Chinese)

$\mathrm{Xu} \mathrm{H}, 2013$. Evolvement, system and characteristics of national park in Japan. World Forestry Research, 26(6): 69-74. (in Chinese)

Zafar S M, Baig M A, Irfan M, 2011. Application of GIS/RS for management zoning of Margallah Hills National Park, Islamabad. International Conference on Environmental Science and Technology, 2: 6-9.

Zhou G S, Zheng Y Y, Chen S Q et al., 1998. NPP model of natural vegetation and its application in China. Scientia Silvae Sinicae, 34(5): 2-11. (in Chinese) 